
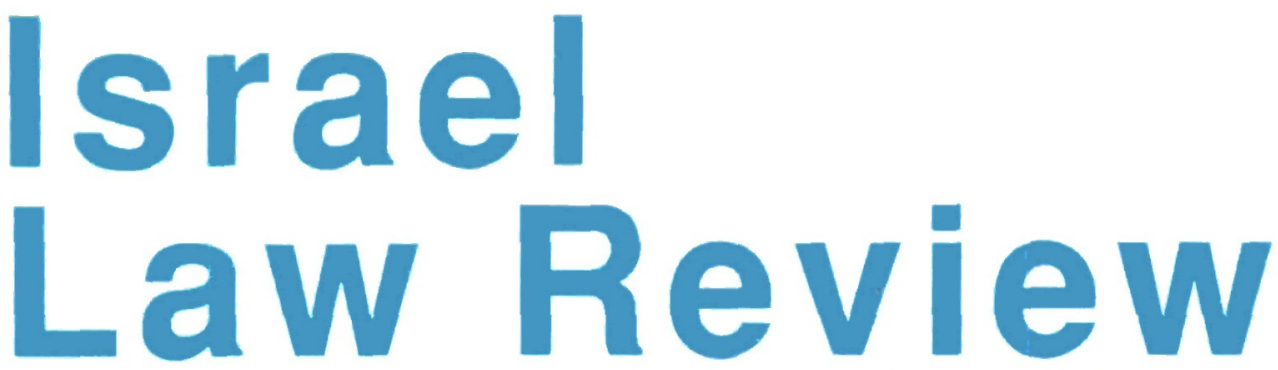

\title{
THE PEACE PROCESS
}

Ruth Lapidoth 207 Introduction

\section{ARTICLES}

Yehuda Z. Blum 211 From Camp David to Oslo

Karin Calvo Goller 236 Legal Analysis of the Security Arrangements between Israel and the PLO

Joel Singer 268 Aspects of Foreign Relations under the Israeli-Palestinian Agreements on Interim Self-Government Arrangements for the West Bank and Gaza

Eyal Benvenisti 297 Responsibility for the Protection of Human Rights under the Interim Israell-Palestinian Agreements

Celia Wasserstein 318 Israel and the Palestinian Authority: Fassberg Jurisdiction and Legal Assistance

Ephraim Kleiman 347 The Economic Provisions of the Agreement between Israel and the PLO

Moshe Hirsch 374 Environmental Aspects of the Cairo Agreement on the Gaza Strip and the Jericho Area

Ruth Lapidoth 402 Jerusalem and the Peace Process

DOCUMENTS 435

BIBLIOGRAPHY 576 


\section{EDITORIAL BOARD}
Chairperson - Cella Wasserstein Fassberg
P. Elman
S. Goldstein
M. Gur-Arye
D. Kretzmer
A.M. Rabello
F. Raday
G. Shalev
S. Shilo
J. Weisman
A. Yoran

Coordinating Editor - Fayge Cohen

Articles Editors - Micah Avni, Douglas Malawsky

The Israel Law Review gratefully acknowledges the very generous financial assistance provided by:

A Permanent Endowment Fund established by Abraham D. Slavitt of Nonwalk, Conn., U.S.A. in memory of his beloved wife, Jennie A. Slavitt

The P.E.F. Israel Endowment Funds in memory of its founder and first president, Judge Julian W. Mack

The Israel Law Review also gratefully acknowledges the financial assistance of the following institutions:

The Faculty of Law, The Hebrew University of Jerusalem

The Ministry of Justice of Israel

The Bernard Lazare Fund

The Nicolas Rosenbaum Endowment Fund

The S.A. Schonbrunn Research Endowment Fund

To be cited: (1994) 28 Is.L.R.

Annual Subscription: US $\$ 42$ including postage

ISRAEL LAW REVIEW

c/o Faculty of Law, Hobrew University,

Moum Scopus, P.O.B. 24100, Jerusalem, lsrael

Telephone: 02-882520, 02-825313

(c) 1994

ISSN 0021-2237 